\title{
The Innovation And Reference Of American Applied Talents' Training Model Under The Background Of "Internet +"
}

\author{
Wang Shiyu \\ Hebei Finance University \\ China's Hebei Province,Baoding City, \\ Heng Xiang North Street,No.3188 \\ 1483586567@qq.com \\ Yang Lei \\ Hebei Finance University \\ China's Hebei Province,Baoding City, \\ Heng Xiang North Street,No.3188 \\ 39576806@qq.com \\ Zhao Xueying \\ Hebei Finance University \\ China's Hebei Province,Baoding City, \\ Heng Xiang North Street,No.3188 \\ 893677452@qq.com
}

\author{
Li Danyang \\ Hebei Finance University \\ China's Hebei Province,Baoding City, \\ Heng Xiang North Street,No.3188 \\ 302811956@qq.com
}

\author{
Chen Ziwei \\ Hebei Finance University \\ China's Hebei Province,Baoding City, \\ Heng Xiang North Street,No.3188 \\ 573131880@qq.com
}

Abstract - Due to industry 4.0, technological progress in particular, the demands of employees professional qualities and skills are ever-growing. As a consequence, one of the problems to be urgently solved in China is how to connect the professional education and talents with industry chain through the Internet to cultivate applied talents who are suitable for economic development under the background of the current reform. This paper focuses on several innovative models of applied talents training in the United States. The teaching model of University Now is affordable and efficient; Minerva Schools at KGI have established a global network teaching model; the teaching model at the University of Pennsylvania is operated as a unified system; the one at University of Phoenix is cooperative and systematic. In the end, under the new situation of the reintegration of educational resources, this paper explains the significance and enlightenment of the innovative development of the applied talents training model in America to the higher quality education in China.

\section{Keywords - Internet+; University Now; American applied talents' training model; Network education; Innovative education}

\section{INTRODUCTION}

In the context of Industry 4.0, the fourth industrial revolution brings the express and swift reformation of the education. In the case of that the global higher education model is rigid and in downturn, rational higher online education turns out with the representative of University Now, MOOC and MOOCs (University of Minerva model), challenge the authority of the traditional educational model. It is the beginning of the innovation of higher education model, to the trend of the stars into the university campus. Just as times pointed out, new educational providers will fade all the flashy garments of higher education - brands, prices and equipment - to make all of us to remind of that the essence of the 
education is studying. This paper would introduce three typical representatives, emphatically elaborate that in the context of Industry 4.0, three kinds of innovative development of American Applied Talents Training Model, and in the situation of that the educational resources reintegrate, the significance of using for reference and the influences on common high quality training in China.

\section{REPRESENTATIVE OF THE UnIVERSITy NOW FOR THE CHEAP AND EFFICIENT TEACHING ModE}

University Now Company was founded in 2010, headquartered at San Francesco. The company is aimed to use the new teaching model and teaching technology to provide online courses with low tuition fee for someone in need, so as to help them get a university degree. The company set the audiences as common staffs on active duty and poor students, who pursue progress, take the minimal tuition fee as an opportunity, attract plenty of serving officers and students. They aim at popularizing higher education, help the educated improve lives and do away with poverty. University Now business model quickly attracts a large number of students for the low tuition fee, quality and quantity guaranteed, diploma degree in real and the flexible systems, maintaining growth of $30 \%$ to $40 \%$ annually and staying profitable.[1]

\section{A. Low Tuition Pattern: Unlimited Courses of 199 Dollars Monthly Payment.}

The cheap teaching model is extraordinary attractive. As a matter of fact, remaining other education characteristics unchanged, students only need to pay 500 dollars for a month at the least, the tuition fee is charged for each month or one system. The types of courses are unlimited in the system, but you can only study one type of course at one time. This model provides with the common university online course, with the charge is also at the acceptable level, the students could gain the enjoyment, flexibility and the operability of the knowledge during the learning process as well, so the courses are popular in the audiences. Besides, the course learning is allowed to sit in on, which means that students could sit in on the lesson without joining the group discussion and answering the question in the classes. Other than that, nothing is different with taking the courses. It is discovered by research that lots of students were enrolled in to become the regular students after sitting in on. The free sit-in-on pattern could make students not only have a rough idea of the courses and teachers, but also save some of tuition fee, because the auditing students also could take the examination to get a diploma.

\section{B. The Real Reliable Diploma.}

University Now has the rights and qualification to issue diplomas and the diploma certification by making acquisition of universities. University Now made a successful acquisition of Andrew Jackson University in 2010 and renamed it as New Charter University. It became the first university to have the network-based distance education for unrestricted access. The New Charter University remains the advantages of convenience, flexibility and the acceptable tuition fee, and provides associate degree, bachelor's degree and master's degree. Due to the approval of the US National Distance Education and Training Committee, New Charter University only has Business School and School of Public Policy. It is possible to expand the scope of teaching to technology, medical treatment, education and so on. University Now is planning to set up more schools in the future, possibly with local characteristics for different countries. The cooperative academy of University Now are widely using network education platform, such as Washington Public Community College and the Bay Area School.[2]

\section{High Quality Teaching.}

University Now ensures high quality teaching through three ways. First of all, internet course teaching courseware are from professional design, guarantee high quality courseware and learning resources, as close as possible to various needs of students to learn. Students could communicate with teachers and classmates in the class, create a good learning atmosphere. During the course, there is interspersed with classroom tests and chapter tests, test grades would be recorded into each student's file, to facilitate students to learn later, make up for knowledge loopholes in time. Second, this kind of study model is really flexible; students can conduct detailed pre-school tests for the subject, the higher level of control can be skipped after the tests and enter the next part directly, with a very high relevance and flexibility. At last, 
each student is accompanied by a learning consultant and course teacher. Learning consultants will develop different learning plans based on the learning ability and time of different students and the course teacher will provide accurate feedback based on the performance and test scores of the different students.

\section{UNIVERSITY of Minerva AS THE REPRESENTATIVE OF THE GLOBAL Network OF TEACHING MODEL}

In 2013, a group of excellent educators and scholars_ — former president of Harvard University, US Treasury Secretary, Larry Summers; Harvard University Department Director of Social Sciences, Director of Behavioral Science Research Center, Stanford University, Stephen Kosslyn; former president of Wharton School, Patrick, all gathered in San Francisco, committed to innovation university education model, founded the University of Minerva. [3]This university has been of great concern since its inception, No school No borders No teacher teaching model is controversial. They main push subversive tradition, using the internet and globalization to attract the eye to wrap themselves, trying to break through the shackles of tradition and realize the realistic innovation of university education model.

\section{A. Admission Criteria.}

The admission criteria of the University of Minerva are different from those of other universities in the United States, not only focus on students' final total score and SAT or ACT test results, but also concentrates on students in high school at all stages of the results and students of their own comprehensive quality and ability. Also, University of

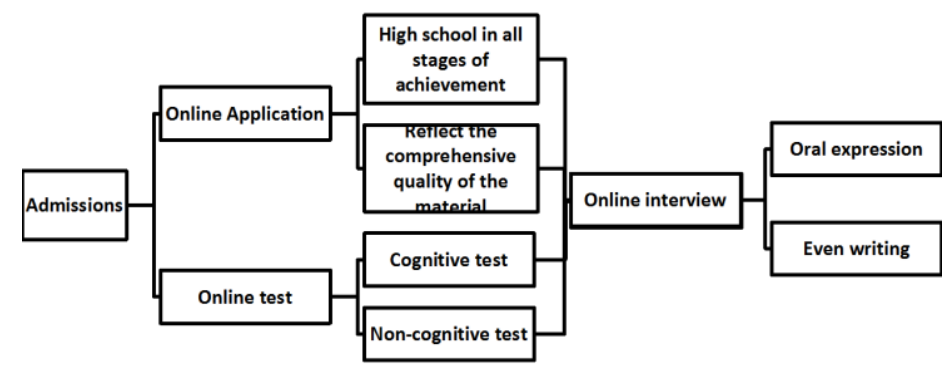

Figure. 1 University of Minerva admissions process

Minerva prefers to admit students who make achievement in academic research and self-employment.

Students are tested for intelligence and personality through some authoritative test, and given a general evaluation, so as to screen out the proactive and creative people of the University of Minerva.[4]

\section{B. Teaching Methods of University of Minea.}

University of Minerva ensures the quality of education carried out by the International Learning Platform. The university refuses the traditional university classroom teaching mode[5], students only need to learn from knowledge by the online course. They envisioned that students would take their own knowledge to participate in the online classroom, enjoy interaction with teachers. Teachers will also examine the system through the inspection of students to learn the enthusiasm, in order to ensure that students can concentrate on the classroom.

Global Immersion Learning style can improve their communicative ability and adaptability. Through seven cities' (San Francisco, Berlin, Buenos Aires, Seoul, Bangalore, Istanbul and London) life, to force students to integrate into local society and to improve their adaptability. They can get to know the customs and living habits of the native people. [6]This model breaks the traditional model which students lived together, help students adapt to society life in advance. Another advantage of this model is that it can help students to learn foreign languages, improve their ability to study independently, immerse themselves into different cultures.

Minerva University has the advantage in the opening course and choosing major. They use small size classes, pay attention to train creative thinking and critical thinking.[7] Minerva University offers professional choice courses in the first year, to assist students find their real interesting. In the second year of their college life, they begin deeply learn ing 
their major. Although Minerva University only provides undergraduate degree for their students, in fact their students have ever reached the level of doctoral students. Compare with other colleges, Minerva University has less majors and courses. They paid more attention to improve students' quality and education quality.[8]

\section{Challenge and Question.}

Based on teaching model and teachers strength, Minerva University are walking in the front of the reform. But outside worlds still are skeptical of Minerva University's claims for what such courses can achieve. Minerva University is a for-profit school, but it tuition fee only one half of other Ivy League schools. How to make a profit and how to achieve their own development, Minerva University's teaching model still needs time to further testing.

\section{NETWORK TEACHING Mode}

In the past few years, American education has been developing rapidly and playing the leading role in the world, but now deadlocked. Compared with traditional education, network teaching mode costs are lower and E-learning community has achieved the realization of lifelong education. Based on its specific characteristics and CIA technology, some colleges have found a road to new teaching mode. Their explorations are in an important influence on Chinese education reform.

\section{A. Basic Model: Teaching Mode.}

Teaching mode including synchronous teaching and remote teaching. Synchronous teaching mode means teachers and students have classes in the same times but different place. Teachers use webcasts to engage in dialogue with their students. Rote teaching refer to the mode which teachers make video recordings in advance, and then they put this video into network, students can watch videos through the Internet. Remote teaching is the basic form of MOOC. In some ways, synchronous teaching can help students to fully understand the knowledge, they can ask question and get reply timely and they also can speak up for teachers. Compared with synchronous teaching, remote teaching is more flexible; students have lower requirements for this mode.

\section{B. University of Pennsylvania: Unified Operation.}

Unified Operation means a university builds a network study platform and other universities can use these resources in their teaching. University of Pennsylvania set "Penn State online" in 1988, they put some course materials in their platform, and these courses are same with the University of Pennsylvania. Every university can apply these resources in their teaching process. University of Pennsylvania's unified operations ensure every branch schools can have the same level teaching resources as Unified Operation. [9]The increased flexibility that has enabled students to study in any of the 40 countries where the school operates. In this mode, University of Pennsylvania can manage upgrades uniformly, avoiding piecemeal implementation, branch schools save teaching cost and improve their teaching quality.

\section{University of Phoenix: Overall Participation Mode.}

Overall Participation mode means networking education combines with traditional education. Universities of Phoenix's principles are facing to the adults and improve in-service officers' professional skills. With the development of Internet, University of Phoenix starts paying more attention to network teaching mode, There developed a practice of a new teaching method which combined the advantages of both network education and traditional education. The target group of the University of Phoenix is adults, so their teaching method is very flexible. On the advance of network education, University of Phoenix make overall planning and branch school just need to execute University of Phoenix's plan. For example, the University of Indianapolis and the University of Kansas City, this two universities allow students using the network to achieve criminal justice and security academic degree. The network has already became an important part of University of Phoenix's teaching process.[10] 


\section{The Enlightenment of American New Teaching Mode}

\section{A. To Create the Network Courses which are Suitable for Office Workers.}

University Now mood is becoming more and more mature. Network teaching mode pays attention to quality training, achieving the aim of practice teaching. In addition to students at school, they provide many learning opportunities for social men. Some people who have no education can improve their ability through network education. Industry 4.0 environments make new demands on science and higher workers quality. However, most Chinese ordinary workers' certificate is low and remains to be improved, many people only have a junior education. Network education can help them improve their personal ability, comply with the requirements of industry 4.0.

\section{B. Minerva University's Extension Model.}

Minerva University's mode is still far away from mature, but still can be referable. Teaching methods of immersion break the traditional higher education mode. "The best way to know this world is tantamount to integrate into this world." Minerva University encourages their students to move around the world. Most Chinese universities can't provide these opportunities for students, but we still can learn lessons from successful experiences of their practice. We should encourage our students to travel extensively.

We should bear in mind that the traditional face to face education is still the main stream of education. We should combine online teaching with below the line teaching; strengthen the interaction between teachers and students. Reinforcing the construction of teachers self-ability and improve the quality of teaching. Pursue to assist in improving student's professional ability.

In our teaching, we should provide a welcome space both ideological and technical where the students may conduct their own choice. Let students are aware of their individual interests and find their favorite subject. Streamline the curriculum to alleviate the burden on students.

\section{Popularizing Network Education.}

Along with the popularization of the network, the network education has become an important model of the education. Different schools have different teaching resources and different development goal. Chinese colleges must rest on their own characteristics, developing their own specific content. Chinese network education is still in the early stage, it's unavoidable to have both good and bad courses. Generally speaking, popularization of MOOC is low. [11]Few people get their degree though network. Chinese network education is a great treasure, its great value need we continue digging.

This work was supported by the grants from Hebei Finance University (The Scientific Fund Project for University Student of Hebei Finance University[2016]No. DXSKYZ2016007 、 Social Science Fund Project of Hebei Province[2016]No. HB16YJ035 、 National Social Science Fund Project[2016]No.16BJY169、 Hebei Provincial Department of Education of Humanities and Social Sciences Major Fund Project [2016]No.ZD201617、Hebei Province Engineering talent cultivation Fund Project[2014]No.A201400358).

\section{REFERENCES}

[1] Q. Wang and Y. Wang, "Analysis of parity higher education represented by University Now”, in Modern Distance Education Research, Vol. 134, D.R.Tian, Eds. Sichuan province: Time and space about academic, 2015, pp. 54.

[2] X.X. Zhao, "MOOC impacts the traditional higher education model”, People's Daily Overseas Edition, Beijing, Vol. 8, pp. 2 , June 2013.

[3] Y.M. Wang, X. Bao and X.J. Wang, "Minerva University: MOOCs era innovation university Pathfinder", in Journal of Distance Education, Vol. 179,Z.D.Wang, Eds. Zhejiang province: Theory Front, 2015, pp. 3.

[4] F.W. Qiang and L. Yan, "Research on system network education development model of American Universities", in Jiaotong University Soc., Vol.11, F.Y. Xu and Z.J. Wang, Eds. Beijing: Education Informatization and Innovation of Educational Technology Talents Training Mode, 2012, pp. 1038-1042

[5] L. Chen, "The new University of Minerva enlightenment education", in University Academic, Vol. 121, Z.G. Yuan, Eds. Beijing: The outside world, 2016, pp. 53. 